\title{
Esportes no Brasil
}

Pesquisa realizada entre setembro de 2005 e junho de 2006 com mais de 2.300 pessoas em 9 capitais brasileiras faz um amplo diagnóstico da situação do esporte no Brasil e fornece informações valiosas para sua gestão no país.

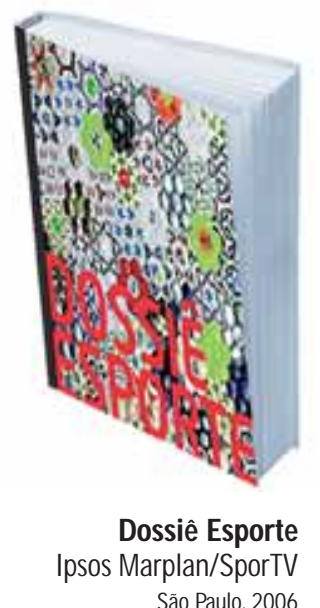

São Paulo, 2006
Apesar de todos os problemas, os esportes demaneira geral eo futebol em particular estão evoluindo no que se refere a gestão, negócios e importância econômica no Brasil. E essa evolução pode ser observada em duas frentes principais. Primeiro, na crescente reputação de que desfruta o esporte na cultura brasileira, com destaque para o futebol. É conhecida a histórica "paixão" do brasileiro por esse esporte, haja vista estar ele presente na linguagem cotidiana das pessoas e nos grandes confrontos entre times.

A segunda é mais recente, mas não menos reveladora: 0 mundo acadêmico tem se voltado para o entendimento do queé o esporte. Cresce o número de estudos, pesquisas e investigações que tomam, como objeto, o esporte - seu impacto econômico, social e cultural. Um importante precedente dessa elevação do esporte como tema acadêmico foram os trabalhos do antropólogo Roberto DaMatta. À luz de sua perspectiva de fazer uma "antropologia do óbvio", ele ajudou a iluminar a importância do mundo futebolístico como uma instituição nacional.

A partir desse precedente, cresceram em quantidade e qualidade estudos e livros publicados sobre o tema no país. Da mesma forma que no mundo acadêmico, havia igual mente no mercado uma expressiva carência de informações sobre, por exemplo, a amplitude da economia esportiva, a relação do brasileiro com o esporte e até mesmo sobre os hábitos de consumo do praticante e do torcedor. Esses estudos são fundamentais para subsidiar ações de desenvolvimento do setor no Brasil.

Entreas ações pioneiras que estão iluminando a gestão esportiva brasileira, vale citar alguns casos: os trabalhos do Ibope sobre as torcidas dos clubes do futebol; os relatórios da consultoria Casual Auditores sobre os balanços dos maiores times; e o trabalho da Fundação Getulio Vargas de mapeamento do PIB do Esporte. Além desses, cabe ainda mencionar o Atlas do Esporte, um esforço coletivo e virtual que está gerando o maior banco de informações esportivas do país. Criado no final de 2005 , esse trabal ho é mantido e constantemente atualizado por pesquisadores do Brasil inteiro e está ajudando a enten der o que éo esporte no Brasil equal o impacto que ele gera na sociedade.

É nesse ambiente de expansão que 
surgiu, no final do ano passado, o Dossiê Esporte, uma publicação produzida pelo Instituto Ipsos Marplan, sob encomenda do canal de TV por assinatura SporTV. Produzida em cerca de dez meses, a publicação inovou na forma de divulgação: além de uma limitada tiragem impressa, direcionada a um grupo específico, há uma versão disponibilizada, na íntegra, na Internet*.

A pesquisa que gerou o DossiêEsporte foi dividida em duas partes. A primeira envolveu 20 discussões em grupo, com um total de 160 pessoas de faixas etárias de 7 a 69 anos, pertencentes às classes $A$, B e C, de São Paulo e Rio de Janeiro. Na segunda fase, uma empresa de pesquisa foi contratada para entrevistar 2.338 pessoas de todas as regiões do país. 0 resultado disso é um mapa atualizado sobre o comportamento nacional no que se refere ao esporte. A primeira surpresa da pesquisa é a gama de modalidades listadas pelos entrevistados. À exceção das opções mais comuns (futebol, vôlei, basquete), surgiram, como práticas esportivas, atividades como caminhada, dança, ioga, peteca e xadrez.

Demaneira geral, entre as conclusões do estudo, ilustradas com gráficos por sexo, idade e regiões do país, observa-se que $94 \%$ da população se interessa por esporte, entre praticantes ou meros torcedores-telespectadores, embora apenas $54 \%$ realizem atividades esportivas regularmente ou com grande freqüência. $\mathrm{Na}$ pesquisa chama a atenção ainda o grande percentual de pessoas que concorda que o esporte está rel acionado à saúde. 0 estudo ajuda a entender a relação do brasileiro com os "ídolos", os gostos esportivos no que se refere à transmissão midiática e 0 hábito de ir a estádios.
Levando em consideração que uma das grandes discussões que estão hoje na pauta da mídia e da sociedade são os altos investimentos exigidos pelos Jogos Pan-Americanos e a possível conquista do Brasil do direito de ser a sede da Copa do Mundo de 2014, informações como essas podem ser importantes para ajudar a entender a formulação das políticas esportivas.

(*) O D ossiêEsporte pode ser acessado em http://globosat.globo.com/sportv/hotsite/ dossie/dossie_esporte.htm

\section{Anderson Gurge}

Mestre em Comunicação e Semiótica pela PUC-SP

Professor da Faculdade de Comunicação Social da Universidade de Santo Amaro (Unisa)

E-mail: andersongurgel@uol.com.br

\section{0 mundo acadêmico e 0 mercado têm se voltado para o entendimento do que é o esporte. Cresce o número de estudos, pesquisas e investigações que tomam, como objeto, o esporte - seu impacto econômico, social e cultural.}

